\title{
Upaya Meningkatkan Kreativitas Anak Dalam Pembelajaran Seni Tari Melalui Strategi Belajar Sambil Bermain di TK Islam Sa'adatul Khidmah Tahun Pelajaran 2016/2017
}

\begin{abstract}
Miskawati $^{1}$
Abstrak: Penelitian ini bertujuan untuk meningkatkan kreativitas anak dalam pembelajaran seni tari melalui strategi belajar sambil bermain di TK Islam Sa'adatul Khidmah Kota Jambi.Penelitian ini merupakan penelitian tindakan kelas. Desain penelitian ini mengacu pada model Kemmis dan Mc Taggart, meliputi perencanaan, pelaksanaan, observasi, dan refleksi. Subjek penelitian ini adalah anak kelompok B TK Islam Sa'adatul Khidmah Kota Jambi yang berjumlah 16 anak, terdiri dari 8 orang anak laki-laki dan 8 orang anak perempuan. Kolabolator penelitian ini adalah guru Seni Tari TK Islam Sa'adatul Khidmah Kota Jambi. Teknik pengumpulan data yang digunakan adalah observasi. Instrumen penelitian ini adalah lembar obsevasi dan catatan harian. Teknik analisis data yang dipergunakan adalah analisis deskriptif baik kuantitatif maupun kualitatif. Hasil penelitian menunjukkan bahwa kreativitas anak dapat ditingkatkan setelah diberi tindakan melalui strategi belajar sambil bermain yang diterapkan pada pembelajaran seni tari. Hasil observasi sebelum tindakan menunjukkan bahwa skor kreativitas rata-rata yang diperoleh anak adalah 57,9. Ada dua aspek kreativitas yang belum berkembang yaitu orisinalitas dan elaborasi. Pada siklus I skor kreativitas ratarata meningkat menjadi 85,83 dan semua aspek kreativitas telah berkembang namun ada dua aspek yang perkembangannya belum maksimal, yaitu fleksibilitas dan elaborasi. Pada siklus II skor kreativitas rata-rata meningkat menjadi 96,66 dan semua aspek kreativitas telah berkembang maksimal. Implikasi dari penelitian ini adalah bahwa guru diseyogyakan menerapkan strategi belajar sambil bermain untuk meningkatkan kreativitas anak dalam pembelajaran seni tari.
\end{abstract}

Kata kunci: Kreativitas, pembelajaran seni tari, strategi belajar sambil bermain

Abstract: This study aims to improve children's creativity in learning dance through learning strategies while playing in Sa'adatul Khidmah Islamic Kindergarten in Jambi City. This study is a classroom action research. The design of this study refers to the Kemmis and Mc Taggart models, covering planning, implementation, observation, and reflection. The subjects of this study were children in group B, Islamic Kindergarten Sa'adatul Khidmah Kota Jambi, which amounted to 16 children, consisting of 8 boys and 8 girls. The collaborator of this research is the Sa'adatul Khidmah Islamic Kindergarten Dance Teacher in Jambi City. The data collection technique used is observation. The research instruments are observation sheets and diaries. The data analysis technique used is descriptive analysis both quantitative and qualitative. The results of the study show that children's creativity can be improved after being given action through play-learning strategies that are applied to dance learning. The results of the observation before the action showed that the average score of creativity obtained by the child was 57.9. There are two aspects of undeveloped creativity, namely originality and elaboration. In the first cycle the average score of creativity increased to 85.83 and all aspects of creativity have developed but there are two aspects whose development has not been optimal, namely flexibility and elaboration. In the second cycle the score of creativity increased to 96.66 on average and all aspects of creativity had grown optimally. The implication of this study is that the teacher will implement a learning strategy while playing to improve children's creativity in dance learning.

Keywords: Creativity, dance learning, learning strategies while playing

\section{PENDAHULUAN}

Pendidikan anak usia dini merupakan batu loncatan yang paling dasar dan berpengaruh besar untuk keberhasilanpendidikan selanjutnya. Sujiono (2010: 6) menyatakan bahwa anak usia dini (dari lahir sampa usia delapan tahun) anak mengalami masa keemasan (the golden years), dimana anak tersebut sangat peka terhadap pengaruh dan perubahan yang berasal dari lingkungan sekitarnya. Pada masa keemasan ini merupakan waktu yang sangat baik untuk mengoptimalkan aspek perkembangannya. Aspek perkembangan anak antara lain meliputi perkembangan fisik dan motorik, perkembangan kognitif, perkembangan bahasa dan berbicara serta perkembangan sosio emosional. Semua aspek tersebut dapat dikembangkan melalui pembelajaran yang ada di pendidikan anakusia dini jalur formal, misalnya Taman Kanak-Kanak (TK),

${ }^{1}$ Tk Islam Sa'adatul Khidmah 
Raudathul Athfal (RA) atau bentuk lain yang sederajat. TK merupakan salah satu wadah yang dapat membantu tumbuh kembang anak sesuai dengan tingkat perkembangannya.

Kreativitas adalah suatu aktivitas imajinatif yang memanisfestasikan kecerdikan dari pikiran yang berdaya untuk menghasilkan suatu produk dan atau menyelesaikan suatu persoalan (Suratno, 2005:24). Salah satu kegiatan yang dapat dikembangkan di Taman Kanak-Kanak adalah kegiatan seni seperti seni tari. Seni tari dapat disesuaikan dengan perkembangan anak TK, karena aktivitas bergerak pada anak TK sangat dominan sehingga pembelajaran melalui tari sangat cocok untuk mengoptimalkan perkembangan gerak/motorik anak.

Dalam kurikulum TK termuat bidang pengembangan kemampuan dasar yang meliputi pengembangan kemampuan seni. Ketika anak mencapai usia 3 sampai 6 tahun telah tampak otot-otot tubuh yang berkembang sehingga memungkinkan mereka melakukan berbagai jenis keterampilan. Jenis keterampilan yang sesuai dengan pembelajaran seni tari yakni perkembangan motorik kasar.

Berdasarkan hasil observasi yang telah dilakukan di TK Islam Sa'adatul Khidmah menunjukkan bahwa umumnya metode yang masih dipakai di sekolah TK yakni metode imitasi, anak hanya meniru gerakan tari yang diajarkan oleh guru tanpa ada proses timbal balik sehingga metode ini justru terfokus pada guru. Oleh karena itu, Metode di TK seharusnya berpusat pada anak. Dampak dari metode terpusat pada guru berpengaruh pula pada aspek-aspek kreativitas anak.Anak-anak kurang berani dalam mengungkapkan ide atau gagasan kreatif dan anak juga kurang percaya diri ketika menari. Oleh karena itu, pembelajaran berpusat pada anak adalah program tahap demi tahap yang didasari pada adanya suatu keyakinan bahwa anak-anak dapat tumbuh dengan baik jika mereka dilibatkan secara alamiah dalam proses belajar. Jika hal ini dibiarkan terus menerus maka anak akan sulit bersikap ataupun berfikir kreatif.

Munandar (2012: 25) menyatakan bahwa kreativitas bisa didefinisikan dalam dua cara: (1) sebagai kemampuan umum untuk menciptakan sesuatu yang baru; dan (2) sebagai kemampuan untuk memberikan gagasan-gagasan baru yang dapat diterapkan dalam pemecahan masalah, atau sebagai kemampuan untuk melihat hubungan-hubungan baru antara unsur-unsur yang sudah ada sebelumnya. Berdasarkan pendapat tersebut maka pendidik dapat mengembangkan kreativitas anak didik sedini mungkin. Kreativitas anak dapat berupa penciptaan produk baru atau pernyataan mengenai gagasan baru dalam memecahkan suatu masalah dengan melihat hubungan-hubungan yang saling terkait.

Menurut Musbikin (2006:6) kreativitas merupakan kemampuan memulai ide, melihat hubungan yang baru atau tak diduga sebelumnya, kemampuan memformulasikan konsep yang tak sekedar menghafal, menciptakan jawaban baru untuk soal-soal yang ada, dan mendapatkan pertanyaan baru yang perlu dijawab. Pernyataan tersebut maka kreativitas merupakan bentuk dari pemikiran seseorang dalam menanggapi suatu persoalan melalui berbagai macam penyelesaian masalah. Kemampuan menyatakan ide-ide baru baik dalam jawaban atas soal-soal yang sudah ada maupun pertanyaan baru yang perlu dijawab.

Kreativitas adalah suatu aktivitas imajinatif yang memanifestasikan kecerdikan dari pikiran yang berdaya untuk menghasilkan suatu produk dan atau menyelesaikan suatu persoalan (Suratno, 2005:24). Dengan kata lain, kreativitas merupakan suatu proses mental yang menghasilkan gagasan atau ide baru dan didukung oleh aktivitas imajinatif dalam pemecahan suatu persoalan maupun menyelesaikan masalah dengan solusi yang tepat. Selain itu, kreativitas juga dapat berupa penciptaan produk baru dan orisinal yang berbeda dengan yang telah ada.

Jamaris (dalam Sujiono, 2010: 38) memaparkan bahwa secara umum karakteristik dari suatu bentuk kreativitas tampak dalam proses berpikir saat seseorang memecahkan masalah. Adapun proses berpikir kreatif muncul karena adanya perilaku kreatif. Lima perilaku kreatif tersebut yakni kelancaran (fluency), kelenturan (flexibility), keaslian (originality), elaborasi (elaboration) dan kepekaan (sensitivity).

Kreativitas dapat semakin berkembang atau bahkan kreativitas dapat hilang karena pengaruh lingkungan anak berada. Perilaku kreatif selanjutnya yaitu kelenturan atau fleksibilitas, berupa kemampuan untuk mengemukakan berbagai macam alternatif dalam memecahkan masalah. Suyadi (2014: 171) menyatakan bahwa keterlibatan diri dalam seni dapat meningkatkan spontanitas dan ekspresi diri, mengontrol efek-efek pembatasan dari inhibisi dan menghasilkan karya-karya kreatif. Oleh karena itu, kreativitas dalam seni tari tari dapat pula dikembangkan sejak anak usia dini dan disesuaikan dengan perkembangan anak TK. 
Munandar (2012: 58-59) memaparkan bahwa potensi kreatif dapat diukur melalui dua cara yaitu tes dan non-test. Pengukuran kreativitas melalui tes meliputi pengukuran dengan berbagai tes kreativitas, di antaranya adalah: 1. Tes yang Mengukur Kreativitas Secara Langsung. 2. Tes yang Mengukur Unsur-Unsur Kreativitas. 3. Tes yang Mengukur Ciri Kepribadian Kreatif. Beberapa pengukuran alternatif melalui tes pengukuran kreativitas non-test, diantaranya yaitu: (1) daftar periksa (Checklist) dan Kuesioner, alat ini disusun berdasarkan penelitian tentang karakteristik khusus yang dimiliki pribadi kreatif. Kemudian, (2) daftar pengalaman adalah teknik ini menilai apa yang telah apa yang telah dilakukan seseorang di masa lalu. Beberapa studi menemukan korelasi yang tinggi antara "laporan diri" dan prestasi kreatif di masa depan. Format yang paling sederhana meminta seseorang menulis autibiografi singkat, yang kemudian dinilai untuk kuantitas dan kualitas perilaku kreatif.

Menurut Kusuma (2007: 53), pendidikan merupakan sebuah proses yang membantu menumbuhkan, mengembangkan, mendewasakan, membuat yang tidak tertata atau liar menjadi semakin tertata, semacam proses penciptaan sebuah kultur dan tata keteraturan dalam diri maupun dalam diri orang lain.

Beberapa pendapat yang telah dipaparkan bermakna bahwa seni merupakan salah satu aspek yang penting dalam dunia pendidikan. Selanjutnya, Suyadi (2014: 165) mengatakan bahwa PAUD mempunyai kontribusi besar bagi pelestarian budaya bangsa melalui pembelajaran seni dengan beragam ekspresinya. Pada anak-anak atau Pendidikan Anak Usia Dini (PAUD), kegiatan bermain, bernyanyi, menggambar, menari (gerak dan lagu) merupakan aktivitas seni yang sangat mendasar. Adapun tarian-tarian dan gerakangerakan selama bermain mampu mengembangkan keterampilan motorik kasar, dan keseluruhan aktivitasaktivitas ini meningkatkan emosional anak.

Oleh karena itu, pendidikan seni tari merupakan suatu pembelajaran yang dapat membatu anak usia dini mengembangkan berbagai kemampuan di masa golden age. Selain itu, melalui seni tari maka pendidik dapat menjadi fasilitator anak untuk mengembangkan kreativitas. Dalam kreativitas anak usia dini, maka yang lebih disorot dan dikembangkan adalah proses kreativitasnya dan identifikasi ciri-ciri anak kreatif.

Perkembangan fisik-motorik meliputi perkembangan badan, otot kasar (gross muscle) dan otot halus (fine muscle), yang selanjutnya disebut motoric kasar dan motorik halus (Suyanto, 2005:49). Suyanto (2005: 50) menambahkan bahwa perkembangan motorik meliputi perkembangan otot kasar dan otot halus. Otot kasar atau otot besar ialah otot-otot badan yang tersusun dari otot lurik. Otot ini berfungsi untuk melakukan gerak dasar tubuh yang terkoordinasi oleh otak, seperti berjalan, berlari, melompat, menendang, melempar, memukul, mendorong dan menarik.

Faktor kognitif mempunyai peranan penting bagi keberhasilan anak dalam belajar, karena sebagian besar aktivitas dalam belajar selalu berhubungan dengan masalah mengingat dan berpikir. Kedua hal ini merupakan aktivitas kognitif yang perlu dikembangkan (Adhiputra, 2013: 66). Pada masa kanak-kanak anak seringkali banyak bertanya tentang apapun, anak ingin tahu mengenai apapun dan anak meniru apa yang dilakukan orang-orang disekitarnya.

Piaget (dalam Suyanto, 2005: 56) menyatakan bahwa anak usia 5 tahun memiliki pola berpikir yang disebut precausal reasoning. Istilah ini digunakan untuk menerangkan hubungan sebab akibat. Tipe-tipe pola pikir ini memuat tentang motivasi, final, fenomenalisme, moralisme, artifisial, animisme dan dinamisme.

Morrison (2012:255) menyatakan bahwa murid TK berada dalam perkembangan kecerdasan dan bahasa yang sangat pesat. Mereka memiliki kapasitas besar untuk belajar kata-kata baru. Murid TK senang dan butuh terlibat dalam banyak aktivitas bahasa. Selain itu, murid TK senang berbicara. Keinginan mereka untuk berbicara harus didorong dan didukung dengan memberi banyak kesempatan untuk ikut serta dalam berbagai aktivitas bahasa sepeti bernyanyi, bercerita, dan membaca puisi. Oleh karena itu, anak-anak usia dini membutuhkan pendamping di sekolah untuk membantu mereka mengembangkan kemampuan bahasa, didorong dan didukung dalam penyaluran pendapat atau ide-ide kreatif yang anak miliki.

Izzaty,dkk (2008: 90) menyatakan bahwa untuk mencapai perkembangan bahasa dan bicara yang dapat melukiskan keadaan secara objektif maka lingkungan harus memberikan masukan pada anak tersebut, karena perkembangan bahasa anak dipengaruhi imitasi. Jadi bila tidak ada yang ditiru atau diimitasi, maka tidak ada input perkembangan bahasa. Selain itu perlu adanya respon dari sekeliling, yakni dari orang-orang yang ada di sekitar anak untuk menanggapi tingkah laku anak 
Masitoh, dkk (2012: 2.15) menyatakan bahwa perkembangan sosial adalah perkembangan perilaku anak dalam menyesuaikan diri dengan aturan-aturan masyarakat dimana anak itu berada. Perkembangan sosial anak merupakan hasil belajar, bukan sekadar hasil dari kematangan. Perkembangan sosial diperoleh anak melalui kematangan dan kesempatan belajar dari berbagai respon terhadap dirinya.

Beberapa jenis emosi yang berkembang pada usia TK seperti perasaan takut, emas, cemburu, kegembiraan, kesenangan, kasih sayang, phobia dan rasa ingin tahu. Semua perasaan tersebut wajar dialami seseorang, bukan hanya anak TK namun orang dewasa juga sering kali merasakan jenis-jenis emosi tersebut. Ada beberapa hal yang dapat dilakukan untuk meningkatkan perkembangan sosial dan emosi positif murid TK, yaitu memberikan kesempatan bagi anak untuk ikut serta secara fisik dan mental dalam aktivitas yang mencakup pemecahan masalah dan aktivitas sosial dengan orang lain. aktivitas tersebut dapat berupa permainan yang ada dilingkungan anak maupun di lembaga pendidikan.

Suratno ( 2005:75) berpandangan bahwa bermain sesuai kodratnya dilihat dari kematangan psikologis, anak usia prasekolah belum siap untuk memasuki dunia belajar seperti halnya anak sekolah pada umumnya. Kegiatan utamanya adalah bermain dan segala aktivitas yang memberikan kesenangan bagi anak. Melalui strategi belajar sambil bermain maka anak dapat mempelajari banyak hal namun tidak kehilangan masa kanak-kanak untuk bermain. Sedangkan, menurut Seels and Richey (1994:34) strategi pembelajaran adalah spesifikasi untuk menyeleksi serta mengurutkan peristiwa-peristiwa belajar atau kegiatan pembelajaran dalam suatu pelajaran.

Fungsi bermain bagi anak TK menurut Masitoh (2012) yaitu mempertahankan keseimbangan dan bermain membantu anak menyalurkan kelebihan tenaga. Pada masa kanak-kanak yang aktif, anak memiliki banyak tenaga yang dapat dipakai untuk berbagai kegiatan. Anak-anak menggunakan tenaga tersebut dalam berbagai bentuk kegiatan, misalnya bermain. Melalui permainan anak dapat melatih keseimbangan tubuh seperti permainan berjalan diatas papan bermain atau permainan tali yang biasa dilakukan anak perempuan.

Menurut jenisnya, maka permainan digolongkan menjadi dua yakni permainan aktif dan permainan pasif. Berikut ini akan diperjelas mengenai jenis permainan aktif dan pasif. Permainan aktif menurut Suratno (2005:82) merupakan kegiatan yang memberikan kesenangan dan kepuasan kepada anak yang dilakukan melalui aktifitas langsung oleh diri anak itu sendiri. Aktivitas anak dalam bermain aktif akan sangat dipengaruhi oleh kondisi anak.

Permainan Pasif menurut Tedjasaputra (2001:63) merupakan permainan yang menghibur (amusement), dalam hal ini anak memperoleh kesenangan bukan berdasarkan kegiatan yang dilakukannya sendiri. Permainan ini merupakan proses bermain yang tidah terlalu membutuhkan aktivitas fisik. Anak tetap akan memperoleh manfaat dari bermain pasif. Jika dilihat dari jenis permainan yang telah dipaparkan, pembelajaran seni tari cenderung kepada jenis pemainan aktif karena anak terlibat langsung dalam pembelajaran. Menurut Fadillah (2014: 36) bahwa permainan yang dilakukan dengan gerakan dapat melatih kekuatan otot sang anak. Melalui belajar sambil bermain, maka guru juga dapat me ngembangkan permainan atau bahkan menciptakan permainan yang sesuai dengan tingkat perkembangan anak dan permainan tersebut dapat diberi nama sesuai dengan persepsi.

\section{METODE PENELITIAN}

Penelitian ini merupakan penelitian Clasroom Action Research (Penelitian Tindakan Kelas). Penelitian ini dimaksudkan untuk meningkatkan kualitas pembelajaran yang dilaksanakan secara sistematik dengan merencanakan, melaksanakan dan merefleksikan tindakan secara kolaboratif dan partisipatif dalam memperbaiki kinerja sebagai guru, sehingga berdampak pada meningkatnya hasil belajar siswa.

Penelitian tindakan kelas yang digunakan dalam penelitian ini mengacu pada model Kemmis dan Mc Taggart yang terdiri dari empat tahapan. Keempat tahapan tersebut meliputi: Perencanaan (planning), aksi atau tindakan (acting), observasi (observing), refleksi (reflecting), yang merupakan satu siklus penelitian. Sesudah suatu siklus diemplementasikan, khususnya sesudah refleksi, kemudian diikuti dengan adanya perencanaan ulang atau revisi. Penelitian ini dilakukan di TK Islam Sa'adatul Khidmah Kota Jambi. Jl. H.Syamsudin Uban Rt.03 No. 58 kel. Tambak Sari.

Teknik pengumpulan data yang digunakan dalam penelitian tindakan ini adalah observasi atau pengamatan. Pengamatan dilakukan secara langsung, yaitu pada saat proses pembelajaran seni tari berlangsung. Pengamatan ini dilakukan untuk mengetahui kesulitan-kesulitan siswa dalam proses tindakan 
dan kondisi proses pembelajaran. Instrumen penelitian ini adalah lembar observasi dan catatan harian. Lembar observasi digunakan agar peneliti lebih terarah dalam melakukan observasi sehingga hasil data yang didapatkan mudah diolah. Lembar observasi tersebut digunakan untuk mengetahui peningkatan kreativitas anak dalam pembelajaran seni tari.. Catatan Harian merupakan salah satu alat yang digunakan untuk mengumpulkan data dengan cara mencatat semua kejadian yang terjadi pada setiap pertemuan. Pencatatan kegiatan harian dilakukan secara langsung, dengan mengamati sebjek penelitian secara bertahap. Kesulitankesulitan yang dihadapi siswa dicatat kemudian dibuat rencara untuk pemecahannya.

Penelitian ini menggunakan analisis deskriptif baik kuantitatif maupun kualitatif, yaitu mendeskripsikan hasil pembelajaran tari di TK Islam Sa'adatul Khidmah. Menurut Paizaluddin (2013: 135) analisis data dilakukan pada tiap data yang dikumpulkan, baik data kuantitatif maupun data kualitatif. Data kuantitatif dianalisis dengan menggunakan cara kuantitatif sederhana dan data kualitatif dianalisis dengan membuat penilaian-penilaian kualitatif (kategori).

\section{HASIL DAN PEMBAHASAN \\ Kondisi Anak}

Berdasarkan hasil pengamatan yang peneliti lakukan terkait dengan aspek perkembangan kreativitas anak khususnya di sekolah, permasalahan yang muncul dan mendominasi di kelompok B yaitu pada perkembangan kreativitasnya. Dalam hal ini anak masih memerlukan bimbingan dalam meningkatkan kreativitas anak. Sebagian besar anak di TK Islam Sa'adatul Khidmah kurang kreatif karena mereka hanya mengikuti dan menirukan semua yang diajarkan guru, anak kurang percaya diri ketika menari, anak-anak juga terpaku pada contoh yang diberikan guru pada saat proses pembelajaran sehingga anak sulit mengingat gerakan tari dan menyesuaikan gerak dengan musik.

Keadaan anak yang telah disebutkan di atas sangat mempengaruhi perkembangan kreativitas anak karena anak tidak memiliki kesempatan untuk mengembangkan ide atau pendapat mengenai tema yang akan dipelajari. Hal tersebut karena anak terbiasa diberi contoh terlebih dahulu tanpa memiliki kesempatan untuk menemukan gerakan yang diperoleh melalui imajinasi anak yang dapat mengembangkan kreativitas anak dalam pembelajaran tari.

\section{Data Awal Kemampuan Anak}

Dalam proses pembelajaran, dapat dikatakan kreativitas anak masih belum berkembang dengan baik. Anak masih bergantung kepada guru dalam pembelajaran. Metode yang dipakai cenderung terfokus pada guru dan anak hanya mengikuti gerakan guru sehingga kreativitas anak kurang dapat berkembang. Pengukuran kreativitas anak dilakukan dengan observasi pra tindakan, peneliti menggunakan lembar observasi yang telah dibuat untuk memperoleh data kteativitas anak pra tindakan. Data yang diperoleh dapat dirangkum dalam tabel 1, skor diperoleh dari jumlah aspek-aspek kreativitas yang berhasil dicapai oleh anak.

Tabel 1.

Skor Kreativitas Pra Tindakan

\begin{tabular}{|c|c|c|c|c|c|c|c|c|c|}
\hline \multirow[t]{2}{*}{ No } & \multirow{2}{*}{$\begin{array}{l}\text { Kode } \\
\text { Anak }\end{array}$} & \multicolumn{6}{|c|}{ Aspek Sebelum Tindakan } & \multirow[t]{2}{*}{ Skor } & \multirow[t]{2}{*}{ Kriteria } \\
\hline & & Kel & Flk & Ori & El & Sen & Total & & \\
\hline 1 & Aqila & 3 & 2 & 1 & 1 & 1 & 8 & 53,3 & Cukup \\
\hline 2 & Cika & 2 & 3 & 1 & 1 & 2 & 9 & 60 & Cukup \\
\hline 3 & Luthfia & 3 & 3 & 1 & 1 & 2 & 10 & 66,7 & Tinggi \\
\hline 4 & Alif & 2 & 2 & 1 & 1 & 3 & 9 & 60 & Cukup \\
\hline 5 & Naufal & 1 & 3 & 1 & 1 & 2 & 8 & 53,3 & Cukup \\
\hline 6 & Gevin & 2 & 3 & 1 & 1 & 2 & 9 & 60 & Cukup \\
\hline 7 & Mahardika & 3 & 2 & 1 & 1 & 3 & 10 & 66,7 & Tinggi \\
\hline 8 & Natasya & 2 & 3 & 1 & 1 & 2 & 9 & 60 & Cukup \\
\hline 9 & Zivi & 2 & 2 & 1 & 1 & 3 & 7 & 46,7 & Cukup \\
\hline 10 & Salsabila & 3 & 2 & 1 & 1 & 3 & 10 & 66,7 & Tinggi \\
\hline
\end{tabular}




\begin{tabular}{lllllllllc}
11 & Radja & 2 & 2 & 1 & 1 & 2 & 8 & 53,3 & Cukup \\
12 & Fauzan & 1 & 1 & 1 & 1 & 2 & 6 & 40 & Kurang Tinggi \\
13 & Sadira & 3 & 1 & 1 & 1 & 2 & 8 & 53,3 & Cukup \\
14 & Bima & 3 & 2 & 1 & 1 & 3 & 10 & 66,7 & Tinggi \\
15 & Zeki & 3 & 2 & 1 & 1 & 3 & 10 & 66,7 & Tinggi \\
16 & Suci & 1 & 2 & 1 & 1 & 3 & 8 & 53,3 & Cukup \\
Rata-rata & & 2,25 & 2,19 & 1 & 1 & 2,38 & 8,69 & 57,9 & Cukup \\
\hline
\end{tabular}

Keterangan:

$\begin{array}{ll}\text { Kel } & =\text { Kelancaran } \\ \text { Flk } & =\text { Fleksibilitas } \\ \text { Ori } & =\text { Orisinalitas } \\ \text { El } & =\text { Elaborasi } \\ \text { Sen } & =\text { Sensitivitas }\end{array}$

Data kreativitas anak pra tindakan menunjukkan bahwa kreativitas anak didominasi pada kriteria cukup sebanyak 10 orang anak. Sedangkan, pada aspek kreativitas orisinalitas dan elaborasi masih rendah. Hal tersebut menunjukkan bahwa kemampuan kreativitas anak dapat ditingkatkan lagi dengan memperbaiki proses pembelajaran seni tari, salah satunya ialah guru dapat menggunakan strategi belajar sambil bermain. Strategi imitasi yang diterapkan pada pembelajaran seni tari di TK Islam Sa'adatul Khidmah kurang mendukung dalam pengembangan kreativitas anak karena anak hanya meniru dan sedikitnya kesempatan untuk anak mengungkapkan pendapat dan berkreasi.

\section{Pelaksanaan Penelitian Tindakan Siklus I}

Masih banyak anak yang belum mencapai indikator-indikator keberhasilan kreativitas yang telah ditentukan. Hal tersebut membuat peneliti berusaha melakukan perbaikan melalui kegiatan pada siklus I. Kegiatan pada siklus I adalah sebagai berikut:

\section{Perencanaan}

Penelitian dirancang dalam tahapan-tahapan yang membentuk siklus pembelajaran. Dalam penelitian ini pembelajaran dilakukan dalam dua siklus. Untuk lebih meningkatkan kreativitas anak, pada siklus pertama dilaksanakan dalam 3 pertemuan. Adapun tahap perencanaan pada siklus I meliputi kegiatan sebagai berikut: 1. Tujuan. 2. Tempat dan Waktu. 3. Personalia. 4. Rincian Kegiatan.

\section{Pelaksanaan Tindakan}

Pertemuan 1 dengan tema Binatang dan Lingkungan. Pelaksanaan tindakan kelas B tidak mengganggu pembelajaran di TK Islam Sa'adatul Khidmah, dikarenakan tindakan ini dilakukan saat jam ektrakurikuler tari.Pertemuan 2 dilaksanakan dengan tema Binatang dan Kebun bunga. Pelaksanaan tindakan kelas B tidak mengganggu pembelajaran di TK Islam Sa'adatul Khidmah.Pertemuan 3 dilaksanakan dengan tema Binatang dan Kebun bunga. Pelaksanaan tindakan kelas B tidak mengganggu pembelajaran di TK Islam Sa'adatul Khidmah.

\section{Observasi Siklus I}

Kegiatan observasi siklus I. Pada kegiatan observasi, yang diamati adalah kegiatan pembelajaran seni tari. Indikator yang diamati yaitu aspek-aspek kreativitas anak dalam menari yaitu aspek-aspek kelancaran, fleksibilitas, orisinalitas, elaborasi dan sensitivitas berupa kemampuan anak mengkondisikan diri dalam menari. Hasil dari observasi siklus I dirangkum dalam tabel 2 hasil observasi siklus I terlampir.

\section{Hasil Tindakan}

Tabel 2.

Skor Kreativitas Siklus I

\begin{tabular}{|c|c|c|c|c|c|c|c|c|c|}
\hline \multirow[t]{2}{*}{ No } & Kode & \multicolumn{6}{|c|}{ Aspek Tindakan Siklus I } & \multirow[t]{2}{*}{ Skor } & \multirow[t]{2}{*}{ Kriteria } \\
\hline & Anak & Kel & Flk & Ori & El & Sen & Total & & \\
\hline 1 & Kaffah & 2 & 3 & 3 & 2 & 2 & 12 & 80 & Tinggi \\
\hline 2 & Bening & 3 & 2 & 3 & 3 & 3 & 14 & 93,3 & Sangat Tinggi \\
\hline
\end{tabular}




\begin{tabular}{cccccccccc}
3 & Muhammad & 3 & 3 & 3 & 3 & 3 & 15 & 100 & Sangat Tinggi \\
4 & Narendra & 2 & 3 & 3 & 2 & 3 & 13 & 86,7 & Sangat Tinggi \\
5 & Dzakirrah & 3 & 3 & 2 & 2 & 3 & 13 & 86,7 & Sangat Tinggi \\
6 & Wihandini & 3 & 3 & 3 & 3 & 2 & 14 & 93,3 & Sangat Tinggi \\
7 & Ahmad & 3 & 3 & 2 & 2 & 3 & 13 & 86,7 & Sangat Tinggi \\
8 & M.Muklis & 2 & 3 & 3 & 3 & 3 & 14 & 93,3 & Sangat Tinggi \\
9 & Jessy & 3 & 2 & 3 & 3 & 3 & 14 & 93,3 & Sangat Tinggi \\
10 & Dhiefany & 3 & 2 & 2 & 3 & 3 & 13 & 86,7 & Sangat Tinggi \\
11 & Kalila & 3 & 2 & 2 & 1 & 3 & 11 & 73,3 & Tinggi \\
12 & Hasna & 2 & 2 & 3 & 1 & 3 & 11 & 73,3 & Tinggi \\
13 & Hajjah & 3 & 1 & 2 & 1 & 3 & 10 & 66,7 & Tinggi \\
14 & Maharaja & 3 & 2 & 3 & 3 & 2 & 13 & 86,7 & Sangat Tinggi \\
15 & Gali & 3 & 3 & 3 & 3 & 2 & 14 & 93,3 & Sangat Tinggi \\
16 & Ibrahim & 3 & 2 & 2 & 3 & 2 & 12 & 80 & Tinggi \\
Rata-rata & & 2,75 & 2,44 & 2,6 & 2,38 & 2,69 & 12,88 & 85,83 & Sangat Tinggi \\
\hline
\end{tabular}

\footnotetext{
Keterangan:

Kel = Kelancaran

Flk $\quad=$ Fleksibilitas

Ori = Orisinalitas

El = Elaborasi

Sen $\quad=$ Sensitivitas
}

Hasil tindakan pada siklus I diperoleh dari penjumlahan skor dari semua aspek kreativitas, kemudian diperoleh skor kreativitas siklus I untuk setiap anak dengan kriteria tinggi dan sangat tinggi. Hal ini menunjukkan bahwa adanya peningkatan jika dibandingkan hasil observasi sebelum tindakan dengan hasil tindakan siklus I. Sebanyak 5 orang anak yang berada pada kriteria tinggi dengan pencapaian skor 66,7, 73,3 dan 80. Selanjutnya, sebanyak 11 orang anak berada pada kriteria sangat tinggi dimulai dengan skor 86,7, 93,3 dan 100.

\section{Evaluasi dan Refleksi}

Setelah mengevaluasi hasil siklus I, ditentukan kendala-kendala yang dihadapi, antara lain sebagai berikut: 1 . Masih ada beberapa anak yang berebut barisan ketika menari. 2. Pada saat menari, masih banyak anak melakukan gerakan tidak sesuai musik. 3. Anak-anak kadang lupa urutan gerak tari. 4. Sebagian anak masih malu-malu mengungkapkan ide-idenya.

Berdasarkan data dari tabel yang diperoleh pada kegiatan menari yang dilakukan pada siklus I menunjukkan bahwa skor kreativitas rata-rata yang diperoleh anak adalah 85,83 dan semua aspek kreativitas telah berkembang namun ada dua aspek kreativitas yang perkembangannya belum maksimal, yaitu fleksibilitas dan elaborasi. Untuk itu, peneliti dan kolaborator sepakat untuk melaksanakan tindakan pada siklus II.

Kegiatan pada siklus II sama dengan kegiatan pada siklus I yaitu kegiatan menari sesuai dengan tema tari di siklus I. Namun, dalam pelaksanaan pembelajaran seni tari pada siklus II berbeda dengan siklus I. Jika dilihat dari setiap aspek-aspek kreativitas maka terlihat bahwa aspek fleksibilitas dan elaborasi masih rendah sehingga pada siklus II, guru memfokuskan pembelajaran untuk anak pada kedua aspek tersebut.

\section{Pelaksanaan Penelitian Tindakan Siklus II \\ Perencanaan}

Diskusi dengan observer mengenai permasalah baru yang muncul pada sikus I, hasil observasi dijadikan dasar menyusun rencana perbaikan pembelajaran di RKH pada siklus II. Untuk lebih meningkatkan kreativitas anak, pada siklus kedua dilaksanakan dalam 3 pertemuan. Adapun tahap perencanaan pada siklus II meliputi kegiatan sebagai berikut: 1 Tujuan. 2. Tempat dan Waktu. 3. Personalia. 4. Rincian kegiatan. 


\section{Pelaksaan Tindakan}

Pada tahap ini, guru melaksanakan pembelajaran sesuai dengan yang telah direncanakan dan disusun dalam RKH. Guru melaksanakan kegiatan dengan bahan dan alat pendukung pembelajaran sama dengan siklus I. Bedanya, pada siklus II ini guru lebih memfokuskan kegiatan pada indikator kreativitas yang masih perlu ditingkatkan, yaitu elaborasi dan fleksibilitas.

Pertemuan 1 dilaksanakan dengan tema Binatang dan Lingkungan. Pelaksanaan tindakan kelas Bmengganggu pembelajaran di TK Islam Sa'adatul Khidmah, dikarenakan tindakan ini dilakukan saat jam ektrakurikuler tari.Pertemuan 2 dilaksanakan dengan tema Binatang dan Lingkungan. Pelaksanaan tindakan kelas B tidak mengganggu pembelajaran di TK Islam Sa'adatul Khidmah, dikarenakan tindakan ini dilakukan saat jam ektrakurikuler tari.Pertemuan 3 dilaksanakan dengan tema Binatang dan Lingkungan. Pelaksanaan tindakan kelas B tidak mengganggu pembelajaran di TK Islam Sa'adatul Khidmah, dikarenakan tindakan ini dilakukan saat jam ektrakurikuler tari.

\section{Observasi Siklus II}

Kegiatan observasi siklus II. Kegiatan observasi yang diamati adalah kegiatan pembelajaran seni tari. Indikator yang diamati ialah semua aspek kreativitas anak dalam menari. Pada siklus II, observasi lebih difokuskan pada aspek fleksibilitas dan elaborasi namun tidak meninggalkan aspek yang lainnya. Hasil dari observasi siklus II dirangkum dalam tabel 3 hasil observasi siklus I terlampir.

\section{Hasil Tindakan}

Setelah dilakukan pengamatan pada siklus II, peneliti mendapatkan hasil observasi siklus I pada tabel 3 di bawah ini.

Tabel 3.

Skor Kreativitas Siklus II

\begin{tabular}{|c|c|c|c|c|c|c|c|c|c|}
\hline \multirow[t]{2}{*}{ No } & \multirow{2}{*}{$\begin{array}{l}\text { Kode } \\
\text { Anak }\end{array}$} & \multicolumn{6}{|c|}{ Aspek Tindakan siklus II } & \multirow[t]{2}{*}{ Skor } & \multirow[t]{2}{*}{ Kriteria } \\
\hline & & Kel & Flk & Ori & El & Sen & Total & & \\
\hline 1 & Kaffah & 3 & 3 & 3 & 3 & 3 & 15 & 100 & Sangat Tinggi \\
\hline 2 & Bening & 3 & 2 & 3 & 3 & 3 & 14 & 93,3 & Sangat Tinggi \\
\hline 3 & Muhammad & 3 & 3 & 3 & 3 & 3 & 15 & 100 & Sangat Tinggi \\
\hline 4 & Narendra & 3 & 3 & 3 & 3 & 3 & 15 & 100 & Sangat Tinggi \\
\hline 5 & Dzakirrah & 3 & 3 & 2 & 3 & 3 & 14 & 93,3 & Sangat Tinggi \\
\hline 6 & Wihandini & 3 & 3 & 3 & 3 & 3 & 15 & 100 & Sangat Tinggi \\
\hline 7 & Ahmad & 3 & 3 & 2 & 3 & 3 & 14 & 93,3 & Sangat Tinggi \\
\hline 8 & M.Muklis & 3 & 3 & 3 & 3 & 3 & 15 & 100 & Sangat Tinggi \\
\hline 9 & Jessy & 3 & 3 & 3 & 3 & 3 & 15 & 100 & Sangat Tinggi \\
\hline 10 & Dhiefany & 3 & 3 & 3 & 3 & 3 & 15 & 100 & Sangat Tinggi \\
\hline 11 & Kalila & 3 & 3 & 3 & 2 & 3 & 14 & 93,3 & Sangat Tinggi \\
\hline 12 & Hasna & 3 & 3 & 3 & 2 & 3 & 14 & 93,3 & Sangat Tinggi \\
\hline 13 & Hajjah & 3 & 3 & 3 & 3 & 3 & 15 & 100 & Sangat Tinggi \\
\hline 14 & Maharaja & 3 & 3 & 2 & 3 & 2 & 13 & 86,7 & Sangat Tinggi \\
\hline 15 & Gali & 3 & 3 & 3 & 3 & 2 & 14 & 93,3 & Sangat Tinggi \\
\hline 16 & Ibrahim & 3 & 3 & 3 & 3 & 3 & 15 & 100 & Sangat Tinggi \\
\hline \multicolumn{2}{|c|}{ Rata-rata } & 3 & 2,94 & 2,81 & 2,88 & 2,88 & 14,5 & 96,66 & Sangat Tinggi \\
\hline
\end{tabular}

Keterangan:

$\begin{array}{ll}\text { Kel } & =\text { Kelancaran } \\ \text { Flk } & =\text { Fleksibilitas } \\ \text { Ori } & =\text { Orisinalitas } \\ \text { El } & =\text { Elaborasi } \\ \text { Sen } & =\text { Sensitivitas }\end{array}$

Dari data yang terdapat pada tabel 3 maka dapat dikatakan ketercapaian kreativitas menunjukkan kriteria sangat tinggi dengan skor 100 sebanyak 9 orang anak, mampu mencapai semua aspek kreativitas dengan baik. Sebanyak 6 orang anak mampu mencapai 4 aspek kreativitas dengan baik dengan persentase 93,3, dan sebanyak 1 orang anak mampu mencapai 3 aspek kreativitas dengan baik dengan persentase 86,7. 


\section{Evaluasi dan Refleksi}

Berdasarkan hasil penelitian siklus II menunjukkan aspek kreativitas anak lebih meningkat dari siklus I. Hal tersebut dapat dilihat dari skor yang dicapai pada kreativitas anak. Melalui kegiatan yang tertera dalam RKH, kemudian diterapkan pada anak melalui 3 kali pertemuan. Data yang diperoleh dari skor pra tindakan, siklus I, dan siklus II yang kemudian diskorkan menjadi skor kreativitas rata-rata. Skor kreativitas anak pra tindakan, siklus I, dan siklus II dirangkum dalam tabel 4, pada halaman selanjutnya.

\section{Tabel 4.}

Skor Kreativitas Anak Pra Tindakan, Siklus I dan Siklus II

\begin{tabular}{lcccc}
\hline No & Kode Anak & Pra Tindakan & Siklus I & Siklus II \\
\hline 1 & Kaffah & 53,3 & 80 & 100 \\
2 & Bening & 60 & 93,3 & 93,3 \\
3 & Muhammad & 66,7 & 100 & 100 \\
4 & Narendra & 60 & 86,7 & 100 \\
5 & Dzakirrah & 53,3 & 86,7 & 93,3 \\
6 & Wihandini & 60 & 93,3 & 100 \\
7 & Ahmad & 66,7 & 86,7 & 93,3 \\
8 & M.Muklis & 60 & 93,3 & 100 \\
9 & Jessy & 46,7 & 93,3 & 100 \\
10 & Dhiefany & 66,7 & 86,7 & 100 \\
11 & Kalila & 53,3 & 73,3 & 93,3 \\
12 & Hasna & 40 & 73,3 & 93,3 \\
13 & Hajjah & 53,3 & 66,7 & 100 \\
14 & Maharaja & 66,7 & 86,7 & 86,7 \\
15 & Gali & 66,7 & 93,3 & 93,3 \\
16 & Ibrahim & 53,3 & 80 & 100 \\
Rata-rata & & 57,9 & 85,83 & 96,66 \\
\hline
\end{tabular}

Dari tabel di atas dapat dilihat secara umum maupun individu maka terlihat bahwa adanya peningkatan kreativitas anak dari pra tindakan, siklus I dan siklus II. Hasil penilaian pra tindakan menunjukkan bahwa 1 orang anak dengan skor 40 sehingga termasuk pada kriteria kurang tinggi, 10 orang anak dengan skor 46,7 60 sehingga termasuk pada kriteria tinggi dan 5 orang anak dengan skor 66,7 sehingga termasuk pada kriteria tinggi. Hasil penilaian siklus I menunjukkan bahwa 5 orang anak berada pada kriteria tinggi dengan pencapaian skor $66,7,73,3$ dan 80 . Selanjutnya, sebanyak 11 orang anak berada pada kriteria sangat tinggi dimulai dengan skor 86,7, 93,3 dan 100. Hasil penilaian siklus II menunjukkan bahwa 16 orang anak telah mencapai kriteria sangat tinggi dengan pencapaian skor 100.

Setelah dilakukan penelitian terhadap anak TK Islam Sa'adatul Khidmah tahun pelajaran 2016/2017 dengan melalui dua siklus penelitian diperoleh hasil penelitian bahwa kreativitas anak dapat ditingkatkan melalui strategi belajar sambil bermain. Penerapan strategi belajar sambil bermain dapat membantu anak agar lebih aktif, berani dan percaya diri dalam proses pembelajaran tari. Selain itu, anak dapat mengemukakan ide-ide ataupun pendapat mengenai tema yang dipelajari, anak dibantu oleh guru dapat merangkai gerak yang disesuaikandengan musik sehingga anak tidak terpaku pada materi yang biasanya telah ditentukan guru. Anak dapat mengembangkan gerak sesuai dengan imajinasi anak dan anak mampu berbaris dengan rapi ketika pratek menari. Strategi belajar sambil bermain tersebut membantu anak mengembangkan aspek kreativitas baik dari aspek kelancaran, fleksibilitas, orisinalitas, elaborasi dan sensitivitas.

\section{SIMPULAN}

Berdasarkan hasil penelitian dan pembahasan yang dikemukakan, maka diperoleh kesimpulan bahwa strategi belajar sambil bermain dapat meningkatkan kreativitas anak TK Islam Sa'adatul Khidmah dalam pembelajaran seni tari. Peningkatan kreativitas anak TK Islam Sa'adatul Khidmah dapat dilihat dari skor kreativitas yang diperoleh anak. Skor minimal yang harus diperoleh anak dalam semua aspek kreativitas 
minimal 61. Kondisi anak pra tindakan menunjukkan bahwa skor rata-rata yang diperoleh ialah 57,9. Sedangkan, pada siklus I skor rata-rata kreativitas anak meningkat menjadi 85,83 dan pada siklus II skor rata-rata kreativitas anak meningkat menjadi 96,66. Semua anak telah mencapai skor diatas 61 sehingga pembelajaran dapat dikatakan berhasil karena anak-anak mampu mencapai skor yang telah ditentukan sebagai kriteria keberhasilan tindakan pada semua aspek kreativitas.

Selanjutnya, peningkatan kreativitas anak TK Islam Sa'adatul Khidmah dapat dilihat dari munculnya aspek-aspek kreativitas anak di antaranya kelancaran, fleksibilitas, orisinalitas, elaborasi dan sensitivitas. Peningkatan semua aspek tersebut dapat terlihat dari data berupa perbandingan sebelum tindakan dan sesudah tindakan mengalami peningkatan pada semua aspek kreativitas anak. Kondisi anak pra tindakan menunjukkan aspek kreativitas anak belum berkembang terutama pada aspek orisinalitas dan elaborasi. Pada siklus I menunjukkan aspek-aspek kreativitas sudah berkembang namun belum maksimal pada aspek elaborasi dan fleksibilitas sehingga tindakan dilanjutkan ke siklus II. Pada siklus II, semua aspek kreativitas anak sudah berkembang dengan baik sehingga dapat dikatakan bahwa kreativitas anak TK Islam Sa'adatul Khidmahmengalami peningkatan yang ditunjukkan dengan perbandingan sebelum tindakan dan sesudah tindakan mengalami peningkatan pada aspek-aspek kreativitas anak.

\section{DAFTAR PUSTAKA}

Arikunto, Suharsimi. 2010. Manajemen Penelitian. Jakarta: Rineka Cpta.

Beetlestone, Florence. 2011. Creative Learning: Strategi Pembelajaran Untuk Melesatkan Kreativitas Siswa. Bandung: Nusa Media.

Gunawan, Adi W. 2003. Genius Learning Study Petunjuk Praktis untukMenerapkan Accelarated Learning. Jakarta: PT. Gramedia Pustaka Utama.

Hollingsworth, Pat dan Gina Lewis. 2008. Pembelajaran Aktif: Meningkatkan Keasyikan Kegiatan di Kelas. Jakarta: PT Indeks.

Kusuma, Doni.A. 2007. Pendidikan Karakter Strategi Mendidik Anak di ZamanColonial. Jakarta: Grasindo.

Kusuma, Wijaya dan Dedi Dwitagama. 2010. Mengenal Penelitian TindakanKelas edisi kedua. Jakarta Barat: PT Indeks.

Masitoh, dkk. 2012. Strategi Pembelajaran TK. Jakarta: Universitas Terbuka.

Morisson, George S. 2012. Dasar-Dasar Pendidikan Anak Usia Dini, EdisiKelima. Jakarta Barat: PT Indeks.

Munandar, Utami. 2012. Pengembangan Kreativitas Anak Berbakat. Jakarta: Rineka Cipta.

Paizaluddin dan Ermalinda. 2013. Penelirtian Tindakan Kelas. Bandung:Alfabeta.

Rachmawati, Yeni dan Euis Kurniati. 2010. Strategi Pengembangan Kreativitaspada Anak Usia Dini Taman Kanak-Kanak Edisi Pertama. Jakarta:Kencana.

Seels, Barbara B and Rita C.Richey. 1994. Teknologi Pembelajaran; Definisi dan kawasannya. Washington. DC: Association for EducationalCommunicatoins and Technology.

Sujiono, Yuliani Nuraini dan Bambang Sujiono. 2010. Bermain Kreatif BerbasisKecerdasan Jamak. Jakarta: PT Indeks.

Sujiono, Yuliani Nuraini. 2011. Konsep Dasar Pendidikan Anak Usia Dini.Jakarta: PT Indeks.

Suratno. 2005. Pengembangan Kreativitas Anak Usia Dini. Jakarta: Departemen Pendidikan Nasional.

Suyadi. 2014. Teori Pembelajaran Anak Usia Dini Dalam Kajian Neurosains.Bandung: PT Remaja Rosdakarya.

Tedjasaputra, Mayke S. 2001. Bermain, Mainan, dan Permainan. Jakarta: PT Grasindo.

Tumurang, Hetty. 2006. Pembelajaran Kreativitas Seni Anak Sekolah Dasar.Jakarta: Departemen Pendidikan Nasional. 